\title{
Konya Alâeddin Camii Mihrap Yüzeyindeki Selçuklu Sülüsü Yazıların Hat Sanatı Açısından Değerlendirilmesi
}

Nihat KA $\breve{G N I C I}$

Bağımsız Araştırmacı, nkagnici@gmail.com

\begin{tabular}{|c|c|}
\hline Makale Bilgileri & ÖZ \\
\hline $\begin{array}{l}\text { Makale Geçmişi } \\
\text { Geliş: } 29.10 .2020 \\
\text { Kabul: } 26.11 .2020 \\
\text { Yayın: } 25.12 .2020 \\
\text { Anahtar Kelimeler: } \\
\text { Alâeddin Camii, } \\
\text { Mihrap, } \\
\text { Selçuklu Sülüsü, } \\
\text { Hat Sanatı, } \\
\text { Hüsn-i Hat. }\end{array}$ & 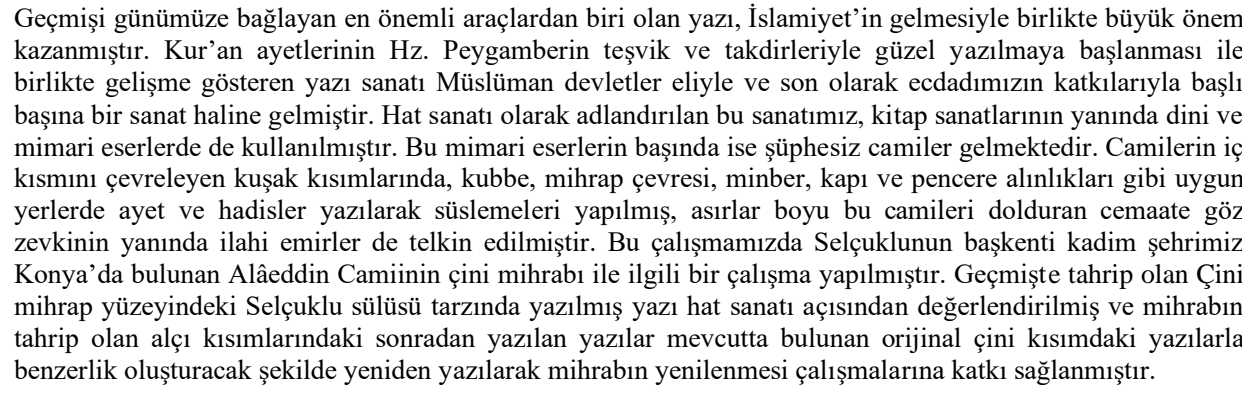 \\
\hline
\end{tabular}

\section{The Evaluation Of Seljuk Sulus Articles On Surface Of The Konya Alâeddin Mosque Tile Mihrap}

\begin{tabular}{|c|c|}
\hline Article Info & ABSTRACT \\
\hline $\begin{array}{l}\text { Keywords: } \\
\text { Alâeddin Mosque, } \\
\text { Mihrab, } \\
\text { Seljuk Thuluth, } \\
\text { Calligraphy, } \\
\text { Hüsn-i Hat. }\end{array}$ & $\begin{array}{l}\text { Writing, which is one of the most important tools connecting the past to the present, has gained great } \\
\text { importance with the advent of Islam. The Quran verses Hz. Muhammed With the encouragement and } \\
\text { appreciation of the Prophet, the art of writing, which has improved with the initiation of writing, has become } \\
\text { an art on its own by the hands of Muslim states and finally with the contributions of our ancestors. This art of } \\
\text { ours, called calligraphy, has been used in religious and architectural works as well as book arts. Mosques are } \\
\text { undoubtedly one of these architectural works. In the sash parts surrounding the interior of the mosques, verses } \\
\text { and hadiths were written in appropriate places such as dome, mihrab, mimber, door and window pediments, } \\
\text { and the congregation that filled these mosques for centuries was inspired by divine orders. In this study, a } \\
\text { study was carried out on the tile altar of the Alâeddin Mosque in Konya, our ancient city, the capital of Seljuk. } \\
\text { The inscription written in the style of Seljuk thuluth on the surface of the ceramic mihrab, which was } \\
\text { destroyed in the past, was evaluated in terms of calligraphy and the post-writings on the damaged plaster parts } \\
\text { of the mihrab were rewritten in a way that resembles the writings on the original tile part, contributing to the } \\
\text { renovation of the altar. }\end{array}$ \\
\hline
\end{tabular}

Atıf/Citation: Kağnıcı., N. (2020). Konya Alâeddin Camii Mihrap Yüzeyindeki Selçuklu Sülüsü Yazıların Hat Sanatı Açısından Değerlendirilmesi, Konya Sanat Dergisi, 3, 79-94. 


\section{GİRIŞ}

\section{Konya Alâeddin Camii Tarihçesi ve Mimari Özellikleri}

Anadolu Selçuklu başkenti olan Konya'da bulunan yapı, Altunapa Vakfiyesine göre iç kalede kasrın ortasında Taht Mahallesinde yer alır. Bu dönemde caminin bulunduğu yerde Medrese-i Sultaniye, Selçuklu Sarayı ve Eflatun Mescidi olarak bilinen Bizans'tan kalma kilise bulunmaktaydı (Konyal1, 1964: 10). Merkezi bir konumda bir tepe üzerinde bulunan cami belki de Konya'da, bir sanatsever için diğer tarihi eserlere oranla ulaşımı en kolay olan Anadolu Selçuklu yapılarından birisidir.

Konya Alâeddin Camii Konya merkezde aynı adı taşıan Alâeddin tepesi üzerine inşa edilmiştir. Camide bulunan kitabelerden caminin Sultan I. Rükneddin Mesud (1116-1156) zamanında yapımına başlandığ 1 ve I. Alâeddin Keykubat zamanında tamamlandığı anlaşılmaktadır. (1221) Kitabelerden caminin banisi olarak I. Mesud, II. K1lıçarslan, I. İzzeddin Keykavus ve I. Alâeddin Keykubad çıkmaktadır.

Cami plan bakımından düzensiz yapıdadır. (Plan-1) Muhteşem bir taç kapıya sahip olan kuzey duvarında başkaca iki kapı daha bulunmaktadır. Caminin bir diğer kapısı ise doğu cephesindedir. Günümüzde giriş çıkış doğu cephesindeki kapıdan yapılmaktadır. Kuzey duvarının dış yüzünde kale ve kervansaraylarda olduğu gibi mahmuz biçiminde payandalar vardır.

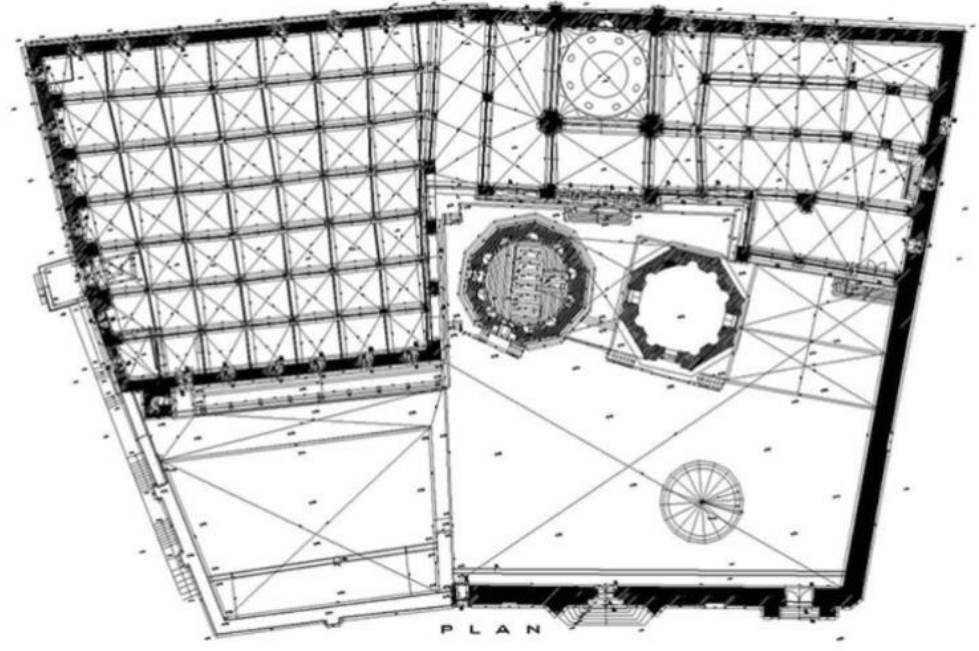

Plan 1. Alâeddin Camii Planı (O. Aslanapa, 1991)

Taş, ahşap, çini gibi farklı malzemeler üzerinde 4 sanatçının ismi geçmektedir. En erken tarihli usta kitabesi abanoz ağacından kündekari tekniği ile yani çivi kullanılmadan iç içe geçme tekniği yapılan şaheser minberde yer alır. Bu kitabeden, kündekari tekniği ile yapılmış minberin 550/1155 yılında üstad Ahlatlı Hacı Birti oğlu Mekki’nin eserinin olduğu anlaşılmaktadır. Kuzeybatıda avluya giriş kapısında yer alan çini madalyon kitabede I. Alâeddin Keykubad döneminde inşaatın hangi zamanında çalıştı̆̆ını bilmediğimiz Erdişah'ın isminin yazılı olduğu görülmektedir. Usta isminin çini üzerinde yazılı olması sebebiyle bazı araştırmacılara göre Erdişah'ın bir çini ustası olduğu tahmin edilmektedir (Konyal1, 1964: 314). I. Alâeddin Keykubad dönemine ait olan diğer bir usta kitabesinde ise mütevelli adı da yazılmıştır. Kuzey cephesinde bulunan kitabede; "Mütevelli Atabeki Ayaz'dır. Şamlı Havlan oğlu Mehmed'in işidir" ibaresi okunmaktadır. Yapıda yer alan bir başka usta kitabesi ise Osmanlı dönemindeki gerçekleştirilen onarımda çalışmış olan ve kalem işlerini yapan hattatın isminin yazılı olduğu kitabedir. Doğu duvarından camiye giriş kapısısnın iç kısmında bulunuan kitabede “...Bu yazıları İsmail Efendi oğlu Mehmed Arif yazdı...” ibaresi yazılıdır (Eyice, 1989: 325). 
Cami avlusunun camiye yakın kısmında Selçuklu sultanlarından I. Mesud, II. Kılıçarslan, I. Gıyâseddin Keyhüsrev, II. Rükneddin Süleyman, III. İzzeddin Kılıçarslan, I. Alâeddin Keykubad, II. Gıyâseddin Keyhüsrev, IV. Rükneddin Kılıçarslan ile III. Gıyâseddin Keyhüsrev’in mezarları bulunan ongen planlı bir türbe inşa edilmiştir. Ayrıca avluda tamamlanmamış sekizgen planlı bir türbe daha vardir.

\section{Konya Alâeddin Camii Çini Mihrabı ve Özellikleri}

Mihrap islam mimarisinde cami, mescid ve namazgâhlarda kıbleyi ve imamın namaz kıldırırken duracağ 1 yeri gösteren mimari elemanın isimdir. Bunlar, cami ve mescitlerde kıble tarafında bulunan duvara oyuk bir girinti şeklinde yapılır. Kökü Arapça olan kelime "saray, sarayın harem kısmı veya hükümdarın tahtının bulunduğu bölüm, Hristiyan azizlerinin heykel hücresi, çardak, oda, köşk, yüksekçe yer, meclisin baş tarafı, en şerefli kısmı manalarına gelmektedir.

Mihrabın dini mimarideki gelişimi uzun bir zamana yayılmıştır. İlk mescitlerden biri olan Mescidi Nebevî'de mihrabının olmadığı sadece Hz. Muhammed'in namaz kıldırdığı yerin belli olduğu bilinmektedir (Erzincan, 1989: 30, 31).

Anadolu Selçuklu ve Türk Beylikleri tarafından inşa edilen cami, mescid, medrese, han ve kümbetler de mihrap önemli bir yere sahiptir. Bu manada mihraplar üzerindeki süslemelerle dikkat çekici bir unsur olarak ortaya çıkmıştır. Ayrıca kullanılan malzemesiyle de farklılıklar göstermiştir. Mihraplar kesme taş, mozaik çini ve alçı malzemeyle yapılmıştır. Mihraplarda zengin geometrik ve bitkisel sülemelerle birlikte yazı kompozisyonlarıda görülmektedir (Öney, 1992: 10).

Konya Alâeddin Camii mihrabı (Resim 1) I. Alâeddin Keykubat döneminde yapıldığı tahmin edilmektedir. Orijinalinde bütünüyle çinilerle kaplıyken halen yalnız kenar bordürlerinin üst kısmında ve köşelikte çini mozaikler kalmıştır. 1889 yılında yapılan onarım sırasında çinileri dökülmekte olan kavsara ve nişin önüne mermer bir mihrap yerleştirilmiştir (Eyice, 1986: 326).

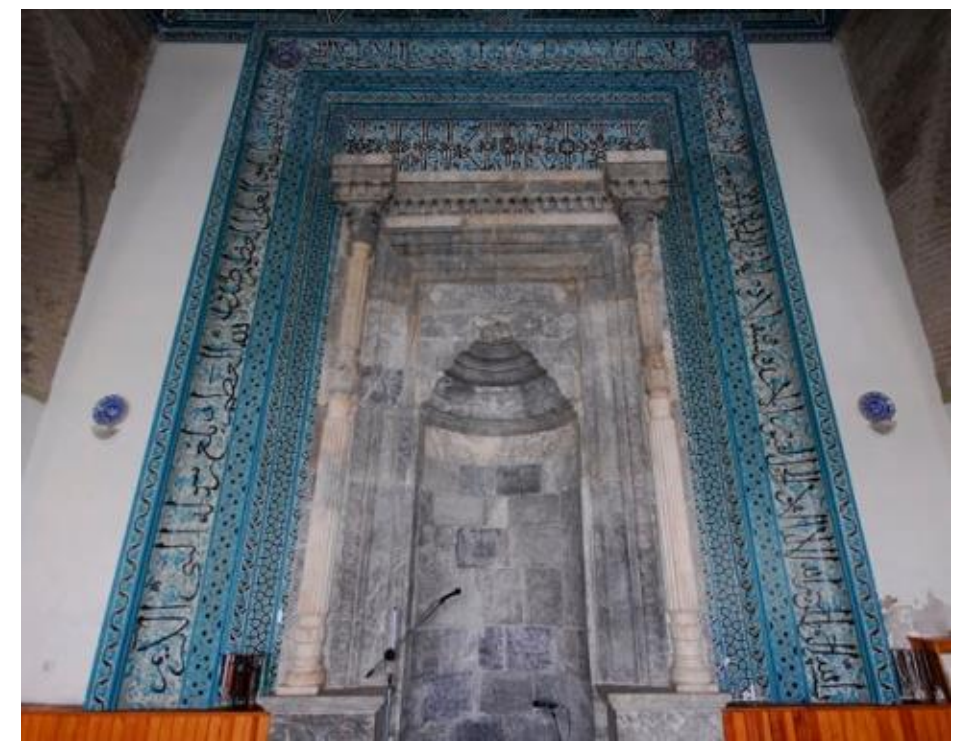

Resim 1. Alâeddin Camii Mihrabı (M. Cambaz)

Anadolu Selçuklu döneminde yoğun bir şekilde yapılmış olan çini mihrapların ilk örnekleri, yapımı XIII. yüzyılın ilk yarısına tarihlenen Konya Alâeddin camii ve Akşehir Ulu camii mihraplarında görülmektedir. (Önge, 1966: 72)

Çini mozaik mihraplarda süsleme unsuru olarak geometrik, bitkisel ve yazı şeritlerinden oluşan motifler kullanılmıştır. Çini plakalarda firuze, patlıcan moru, kobalt mavisi, siyah renkler 
kullanılmıştır. Ayrıca bu renklerin yanı sıra beyaz harç dolgunun da bir renk olarak katkısı vardır. Bu çinilerde mozaik karakteri gösterdiği için mozaik çini denilmektedir. Bu tekniğin yuvarlak ve düz yüzeylere montajı uygun olduğu için birçok yerde kullanıldığı görülmektedir (Akok, 1972: 214).

Mihrap yüzeyi firuze ve siyah renkli çiniler ile, kenar bordürleri ise yazı ve bitkisel bezemelerle kaplıdır. İç bordürler ise geometrik motifler ile oluşturulmuş kompozisyonlar ile bezenmiştir. Bordürdeki yazı Ayet-el kürsi olarak bilinen Bakara suresi 255. Ayetidir. Mihrabın çevresini genişlikleri farklı altı sıra bordür şeridi dolaşır. Her bordürün arasında $2 \mathrm{~cm}$ lik basamaklar vardır. (Çizim 1) $590 \mathrm{~cm}$ x $785 \mathrm{~cm}$ boyutlarındaki mihrabı çevreleyen bordürler mihrap nişine doğru kademelerle derinleşmektedir.

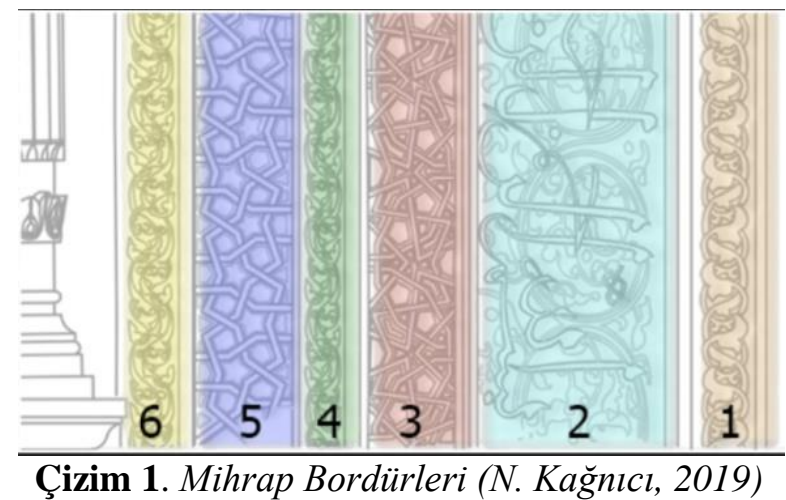

Birinci bordür; Düz silmeli olup $14 \mathrm{~cm}$ genişliktedir. Bu bordürde süsleme bakımından; Alçı zemin üzerine firuze renkli, helezonlar üzerine yuvarlak formlu yarım çift iplik formunda rumi aşağı ve yukarı doğru kıvrılarak sıralanmıştır. (Resim 2)

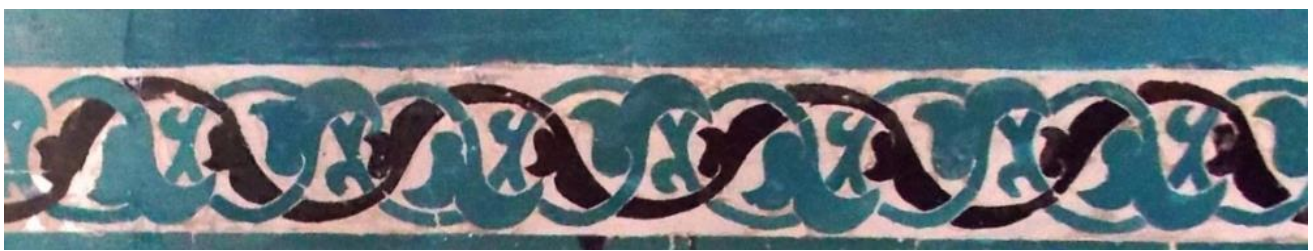

Resim 2. Birinci bordür detayı (N. Kă̆nıcı, 2019)

İkinci bordür; $45 \mathrm{~cm}$. genişliktedir. Bordürde bitkisel süslemeler vardır. Bordürü Selçuklu tarzında yazılmış sülüs yazı tamamlamaktadır. Beyaz alçı zemin üzerinde firuze renkli iç içe geçmiş çifte daireler meydana getiren helezon motifleri ve bu kıvrımlar üzerinde yapraklar ile rumi motiflerinden oluşan bitkisel kompozisyon yer almaktadır. Bordürde Ayet-el Kürsi olarak bilinen Bakara Suresi'nin (Sure-2) 255. Ayet-i Kerimesi yazılmıştır. (Resim 3)

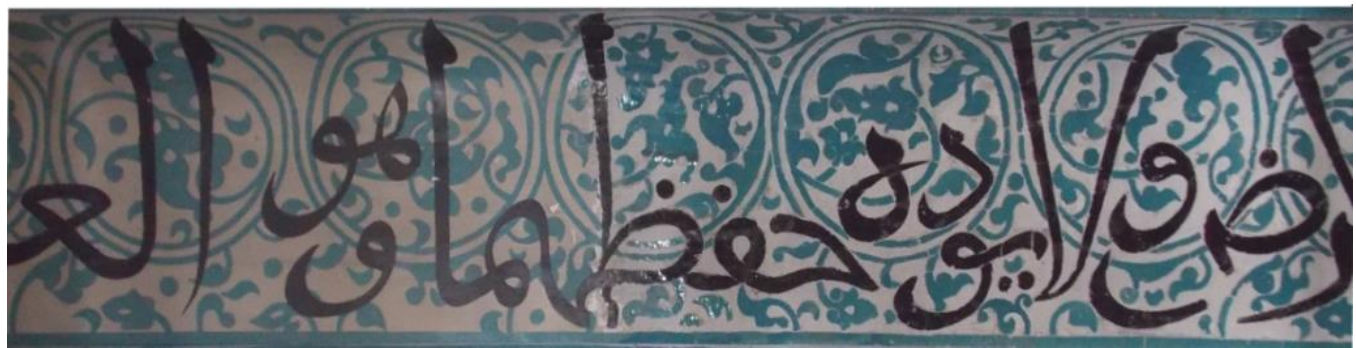

Resim 3. İkinci Bordür Detayı (N. Kağnıcı, 2019) 
Üçüncü bordür; Diğer bordürlere göre daha dar ve düz olup, $25 \mathrm{~cm}$ genişliktedir. Süslemeler geometrik tekrarlı bir kompozisyondan oluşmaktadır. (Resim 4)

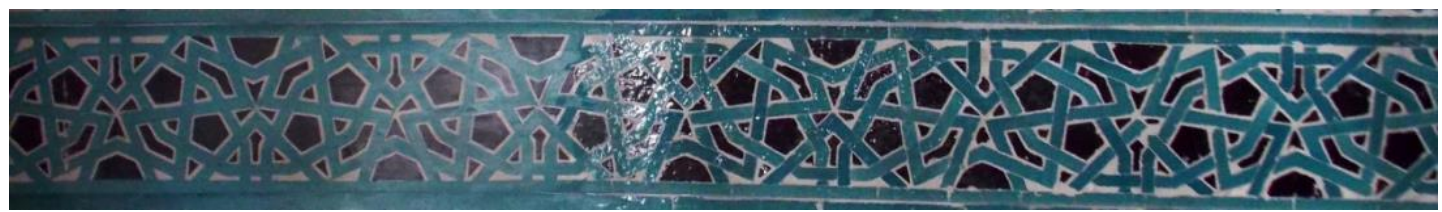

Resim 4. Üçüncü Bordür Detayı (N. Kağnıcı 2019)

Dördüncü ve altıncı bordür; $18 \mathrm{~cm}$. genişlikte düz zemin olup, Alçı zemin üzerinde firuze ve manganez moru mozik çinilerden kesilmiş ikili rumi geçme motifler yer almaktadır. (Resim 5)

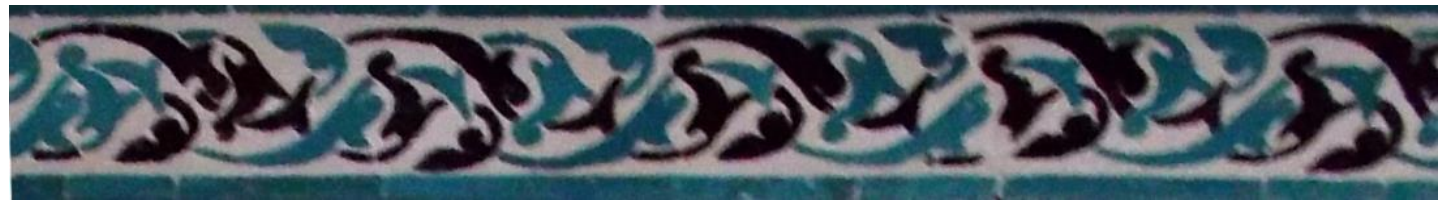

Resim 5. Dördüncü ve Altıncı Bordür Detayı (N. Kă̆nıcı)

Beşinci bordür: $27 \mathrm{~cm}$. olan düz bordür süslemelerinde; Firuze zemin üzerine manganez moru renkli ince çini şeritlerden oluşan geometrik örgülü motif bulunmaktadır. Bu motifin iç kısımlarında kalan boşluluklar ise yıldız ve beşgenleri oluşturmaktadır. (Resim 6)

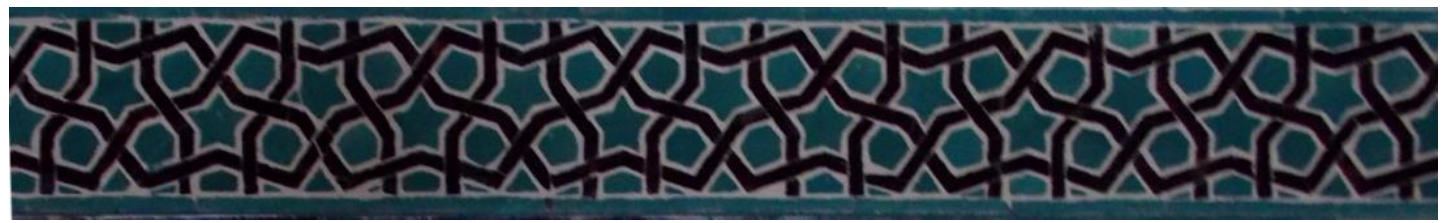

Resim 6. Beşinci Bordür Detayı (N. Kăgnıcl, 2019)

Alınlık: Mihrap nişinin üst kısmında yer alan alınlık kısmında bitkisel örgü zemin üzerinde kufi yazı şeridi yer almaktadır. Firuze renkli ince çini şeritlerden helezoni kıvrımlar ve bu kıvrım dallara eklenen palmet yaprakları yan yana dört büyük daire meydana getirerek zemini doldurmaktadır. "Çiçekli kufi " olarak bilinen yazı karakteriyle Bismillahirrahmanirrahim Elmülkülillah (Bağışlayan ve esirgeyen Allah'ın adıyla mülkün sahibi Allah’dır) yazmaktadır. (Resim 7)

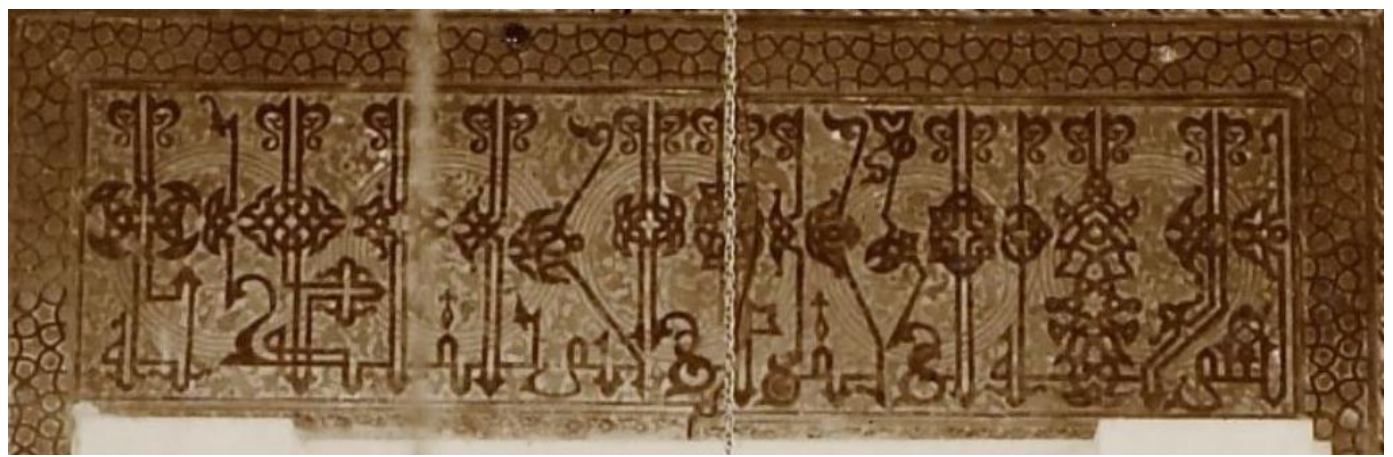

Resim 7. Alınlık Detayı (N. Kağnıcı, 2019)

Mihrabın yerden yaklaşık $5 \mathrm{~m}$. kısmı bilinmeyen bir zamanda tahrip olmuştur. Tahrip olan çinili kısım yerine günümüzde alçı malzemeden yapılmış bir bölüm ve üzerine gerçeğe yakın renklerle bezenmiş süslemeler ve yazı yer almaktadır. (Çizim 2) 


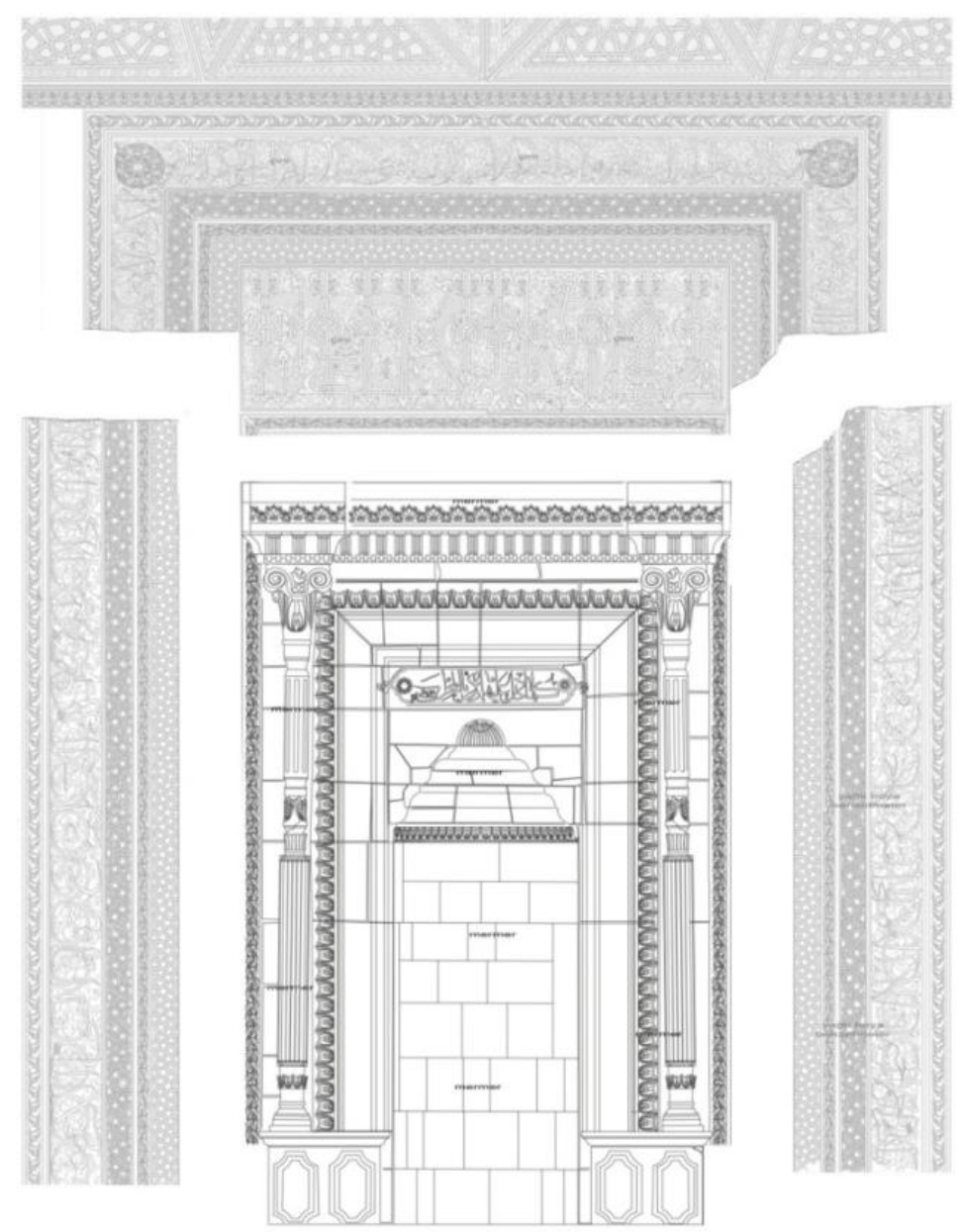

Çizim 2. Mihrap Bölümleri (A. Kocadağıstan)

Orta kısımda ise 1889 'da yapılan tamir sırasında yerleştirilmiş mermer mihrap vardır. $\mathrm{Bu}$ tamir sırasında burada olan çiniler ya kapatılmış ya da tahrip olmuşur.

\section{Hüsn-i Hat Sanatı ve Selçuklu Sülüsü}

"Hüsn" kelimesi Arapçada güzellik "Hat" ise çizgi ve yazıya benzer şeyler manasını taşımaktadır. Bu kelimelerin birleşmesiyle meydana gelen "Hüsn-i hat" ise güzel yazı anlamına gelmektedir.

Sanat terimi olarak ise belirlenmiş olan estetik kural ve kaidelere bağlı kalarak Arap harfleriyle ölçülü ve güzel yazı yazma sanatıdır. Kısaca "Hat sanatı" olarak da adlandırılan bu sanat dalını icra eden kişilere ise "Hattat" veya "Hüsn-i Hat Sanatçısı" adı verilmektedir.

Medeniyetin gelişiminde katkısı olan ve önemli bir icat olan yazı, yaşanılan dönemlere göre çeşitli şekiller alarak gelişme göstermiştir. Zamanla sanat olarak bir kimlik kazanmış ve her medeniyette kendine yer bulmuştur. Batı medeniyetlerinde kaligrafi adını alan yazı doğuda yani İslam medeniyetinde ise Hüsn-i hat adını alarak yaşamın bir parçası haline gelmiştir.

İslamiyet'in gelmesiyle birlikte mevcut güzellik duygusu her alanda gelişme gösterdiğ gibi yazı sanatında da gelişmiş ve olgunlaşmıştır. Zamanla bir sanat haline gelen yazı usta sanatçıların elinde şekillenerek farklı tür ve yollara ayrılmış, günlük hayatın çerçevesinde kendine yer bulmuştur.

Hüsn-i hat sanatı Arap alfabesine bağlı olarak çeşitlenmiş ve şekillenmiştir. Hazret-i Muhammed (s.a.v)'in vahiy katipleri tarafından Kuran-1 kerimi kayıt altına aldırması sürecinde güzel 
yazıyı teşvik ve yazılan ayetlerin yanlış yazılmaması husunda söylediği sözleri ve güzel yazıyı teşvikleri bu sanatın gelişmesinde büyük önem sağlamıştır.

İslam dininin bilime verdiği özel önemin etkisiyle, Emeviler ve Abbasiler döneminde birçok katip yetişmiş, bu katipler sayesinde yazı bir sanat haline gelerek mimarlık, bezeme sanatları ve musiki gibi önemli bir sanat kolu olmuştur.

Yazının gramer olarak olgunlaştığı dönem ise Emeviler dönemidir. Bu dönemde harflerin ve kelimelerin ölçüleri belirlenmiştir. Abbasiler devrinde ise Sülüs ve Nesih yazılarının İbn-i Mukle (885-940) tarafindan ortaya konduğu kabul edilir. İbn-i Mukle'nin (885-940) nizam ve âhengini kaidelere bağladığı "mensûb hat" doğmuştur. XI. Asrın başlarında muhakkak, reyhânî ve nesih hatları doğmuştur. İbnü’l Bevvâb (ö.413/1022), İbn-i Mukle, yolunu değiştirmiş ve bu üslûb XIII.yüzyılın ortalarına kadar devam etmiştir. Aynı yolda çalışan XIII. yüzyılda Yâkût el-Musta'sımî (ö.698/1298) aklâm-1 sitte denilen sülüs, nesih, muhakkak, reyhânî, tevki' ve rikâ' adı verilen altı çeşit yazıyı en gelişmiş şekliyle tespit etmiştir (Derman, 1987: 428).

Yazının mimaride ilk kullanımına ise yine Emeviler (661-750) döneminde rastlanmaktadır. Halife Abdü'l-Melik'in (685-705) 687 tarihinde yapımına başladığı Kubbetü's-Sahra yazının kullanıldı̆̆ ilk örnek olması bakımından dikkat çeker (Gün, 1992: 2).

Yazının mimaride bir unsur olarak kullanılışı Selçuklulara gelinceye kadar diğer bütün İslam devletlerinde görülmektedir. Mimari eserlerin yazıyla bezenmesi yeni bir düşünce değildir, fakat bunun İslâm ülkelerinde kullanılan boyutları ve şekilleri çok ileri seviyelerde görülmüştür. Yazı özellikle dinî mimarîde kapı alınlarında pencere üstlerinde kuşak kısımlarında kullanılmıştır. Ayrıca taşınabilen eşyalarda Kur'an-1 kerim, rahlelerinde kullanılan yazı, ana formları güçlendirmek ve tamamlamak adına sandukalarda, şamdanlarda, vb. yerlerde de kullanılmıştır.

XII ve XIII. yüzyıllarda anıtsal mimaride Selçuklu tarzı sülüs yazı gelişmiş, dini yapılarda özellikle mihrap, minber, panolar ve alınlıkarda kullanılmıştır. Bu yazı türünü daha önce kullanılan celi sülüs yazıdan ayıran belirgin temel özellikler vardır. Alâeddin Camii mihrabı incelenirken Selçuklu tarzı sülüs yazıyı diğer yazılardan ayıran özelliklerden ve farklardan bahsedilecektir.

Selçuklu tarzı sülüs yazıdan önce mimar yapılarda kûfî tarzı yazı, kâğıt üzerinde ise muhakkak ve reyhanî hatları kullanılmıştır. Miladî VII. yüzyılın sonlarına doğru Arap yazısında değişikliğe gidilmiştir. Bu tarihlerde noktalama ve harekeleme işlemlerine ihtiyaç duyulmasıyla birlikte farklı yazı çeşitlerine de ihtiyaç duyulmaya başlanmıştır. Bu ihtiyaçlarla birlikte yazı çeşitlenmiş, artık kûfî yazı kâğıt üzerinde kullanılmaktan vazgeçilerek; yerini daha yumuşak çizgilere, daha hareketli bağlantılara ve daha çok armoniye sahip olan muhakkak ve reyhanî hatları kullanılmıştır.

Selçuklu sülüsü Muhakkak hattının daha hareketli bir tarzını ortaya koymaktadır. Yapısında sülüs karakteri olan 1/3'lük sistem görülmekte olup yazıya bir kıvraklık katmaktadır. Selçuklu sülüsünün ana karakterlerinden biri de dik harflerin bir çiviyi andırır vaziyette yukarıdan aşağıya sivrilerek gelmesi olarak tarif edilebilir. İstif formlarında ise baskın karakteri dik harflerin yan yana dizilerek bir kompozisyon oluşturmasıdır. Kompozisyonlarda genellikle harflerin eğimlerine çok dikkat edilmemiş, özellikle dik harfler aynı yazı içerisinde dahi sağa veya sola meyilli olarak yazılmıştır.

\section{Mihrap yüzeyinde bulunan Sülüs Yazlları ve Çözümlemeleri}

Mihrabın her iki yönünden zeminden başlayarak yaklaşık 5,5 metresi günümüze ulaşmamıştır. Tahrip olan çinili bölümlerde bulunan yazı ve desenler yenileme çalışmaları sırasında üst kısımda bulunan yazı karakterine ve desenlere uygun olarak alçı malzeme üzerine yağlı boya ile tatbik edilerek mihrabın yazı ve desen bütünlüğü sağlanmaya çalışılmıştır. (Çizim 3) Mihrabı çevreleyen yazıda 
Bakara Suresi'nin (Sure-2) 255. Ayet-i Kerimesi olan Ayet-el Kürsi yazmaktadır.

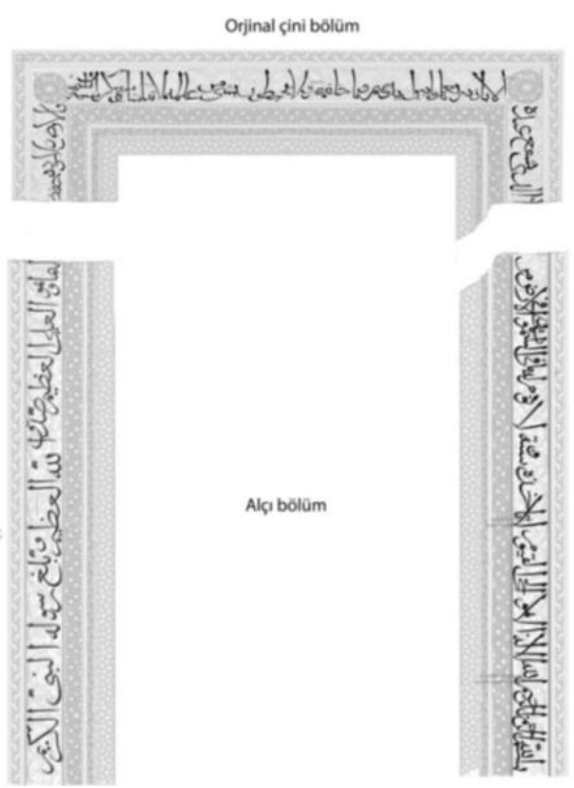

Çizim 3. Mihrabın Orijinal ve alçı bölümleri (A. Kocadă̆ıstan)

Mihrap yazılarını hat sanatı açısından değerlendirirken tahrip olmayan orijinal çini kısmın yazıları üzerinden değerlendirme yapacağız. (Resim 8)

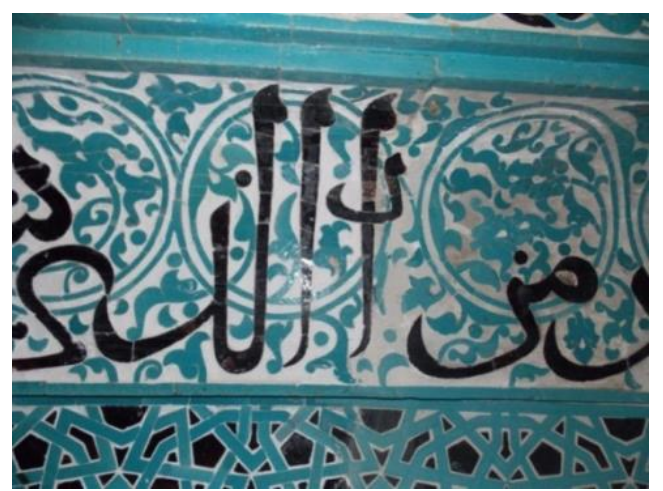

Resim 8. Mihrabın orijinal çini kısmından bir örnek (N. Kağnıcı)

Celi tarzda Selçuklu sülüsü ile yazılmış olan yazı mihrabın sağ alt köşesinden başlayarak sol alt kısımda bitmektedir. Yazı genel olarak Selçuklu sülüsü’nün karakterini yansıtmaktadır. Bu özellikler dik harfleri kalın başlayıp ince bitmesi ve alt uçlarının sola kıvrılması, çanaklı harflerin yuvarlak olması ve harf zülfelerinde bulunan rumi motifleridir (Günüç, 1996: 73).

Karatay Medresesi'nin iç kısmında eyvanın kenarlarında bulunan kuşak yazısında yine Bakara suresinin 255 ayeti kerimesi yazılmıştır. (Resim 9) Karatay Medresesinde bulunan yazılar ve Alâeddin Camii Mihrap yazılarının aynı karakterde yazıldığı görülmektedir. Mimari açıdan aynı özellikler taşıyan her iki eserin mimarlarının Havlan el-Dımaşki (Erdemir, 2009: 26-30) olduğu düşünüldüğünde aynı üslup içinde mütalaa edilebilecek bu yazıların hattatlarının da aynı olduğunu düşünmek mümkündür. 


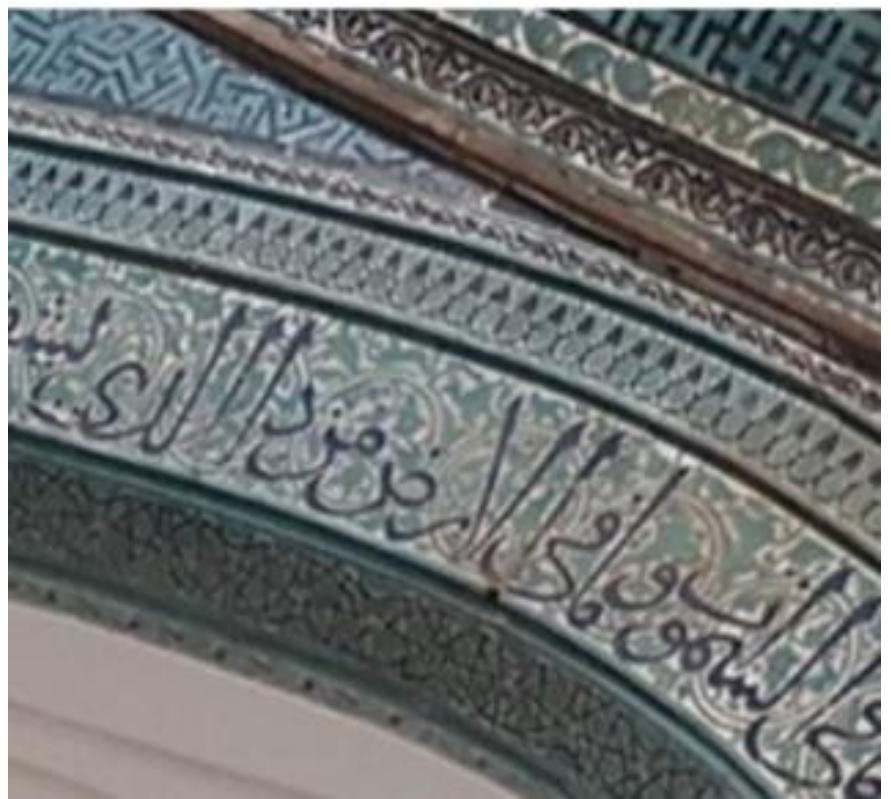

Resim 9. Karatay Medresesi’nde bulunan yazı örneği (N. Kağnıcı)

Besmele ile başlayan kuşak yazısında "be" harfi ve "Lafzatullahın" zülfeleri yine "elif" harflerinde olduğu gibi yuvarlak ve rumi motifli olarak yapılmıştır. Dikkat çeken bir diğer husus bazı işaretler ve harekelerin orijinal çini kısımda olmayıp alçı üzerine yağlı boya ile yapılmış alt kısımda yapılmalarıdır. (Resim 10)

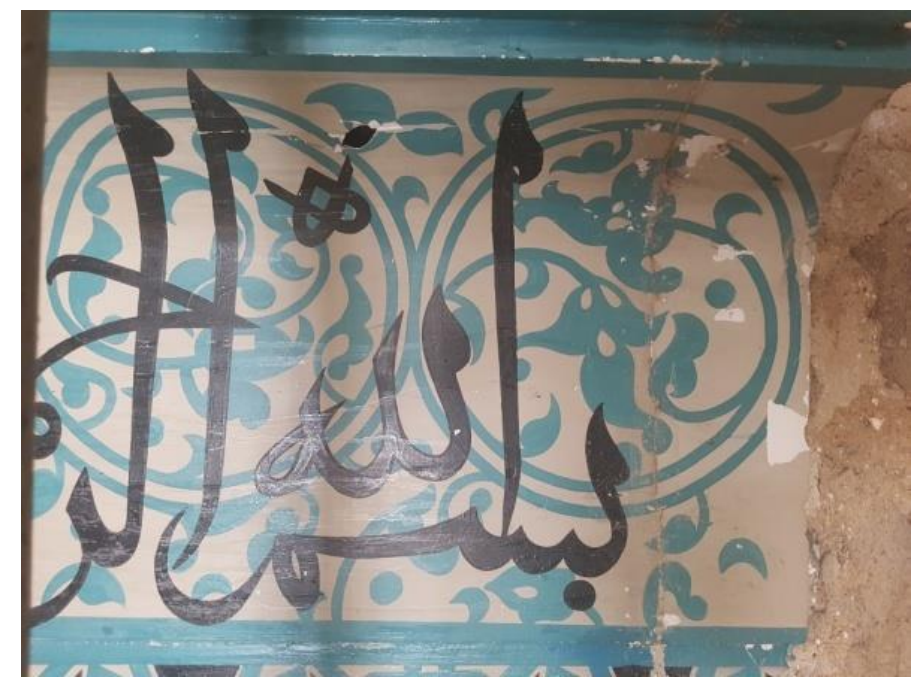

Resim 10. Mihrap yazı örnĕgi (N. Kă̆nıcı)

Ayeti kerimenin başladığı kısımda bulunan "Lafzatulahın" "he" harfi yine düzeltmeler sırasında eksik yazılmıştır. Bunu yazan kişinin ehil olmadığını göstermektedir. (Resim 11) 


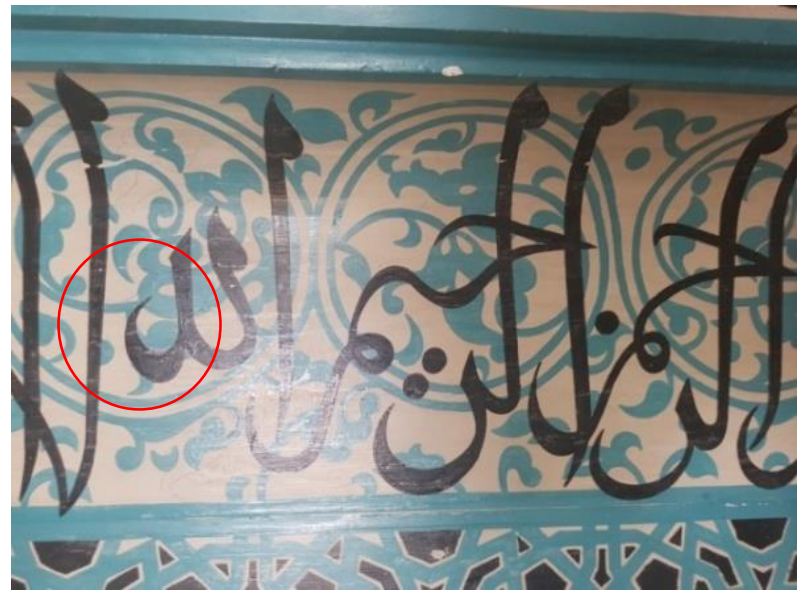

Resim 11. Mihrap yazı örneği (N. Kăgnıcl)

Dikey harflerin bir sıra halinde yazı içersinde kullanılması yazının ahengini gösteren en önemli unsurlardandır. Sanatçı "lamelifin" "elif" harfini "hüve" harfinin içerisinden geçirerek güzel bir görünüm meydana getirmiştir. (Resim 12)

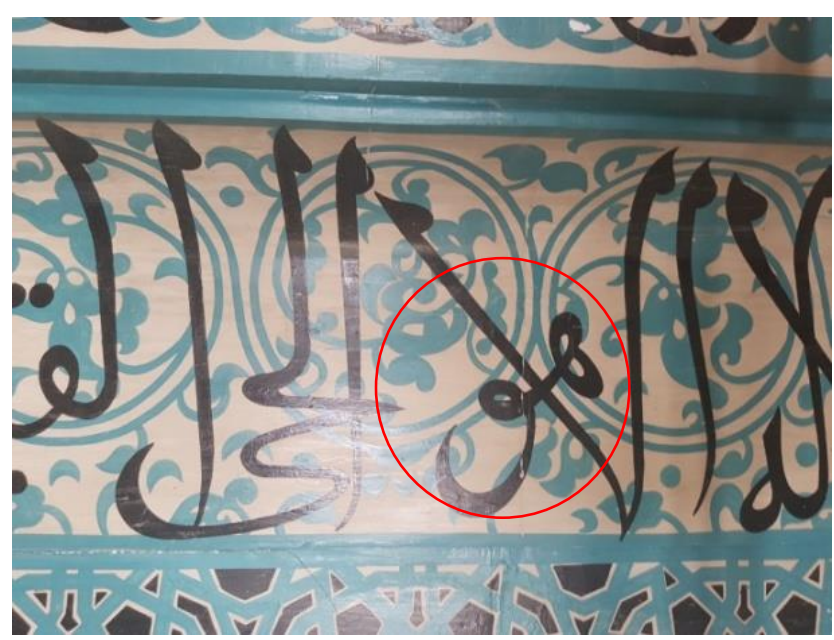

Resim 12. Mihrap yazı örnĕ̆i (N. Kă̆nıcı)

Arapçada "elif" ve "lam" harflerinin başlangıcına konulan noktalara zülfe adı verilmektedir. "La te'huzühü" kelimesi yazılırken "te" harfinden sonra gelen "elif" harfi ne zülfe konulması okunan "elif" harfine zülfe konulduğunu göstermektedir. Yazının orijinal bölümünde yer alan "İlla biiznih" kelimesinde aynı kullanım görülmektedir. (Resim 13)

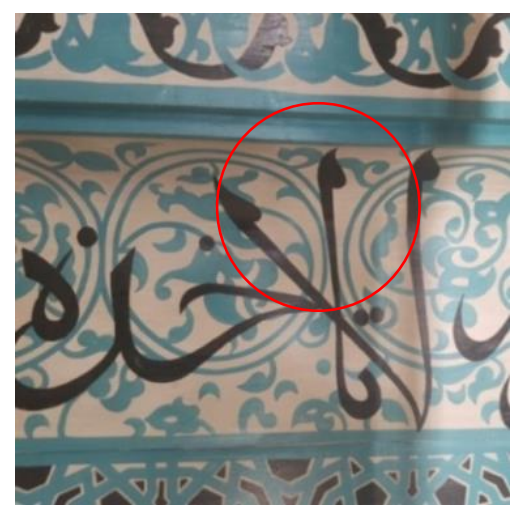

Resim 13. Mihrap yazı örneği (N. Kă̆nıcl) 
Orijinal çini bölümün başladığı "elleziyeşfeu” ayetlerinin bulunduğu bölümde dik harflerin muntazam bir şekilde sıralanışı ve "elif" harflerinin uçlarının kıvrık oluşu dikkat çekmektedir. "yeşfeu" kelimesinde "şın" dişlerinin ahengi ve kalemin incelik ve kalınlığının hattat tarafından gayet latif bir şekilde kullanılışı ayrıca ye harfindeki zülfenin harfin bünyesine uygun büyüklükte yazılması yazıyı güzelleştiren unsurların başında gelmektedir. (Resim 14)

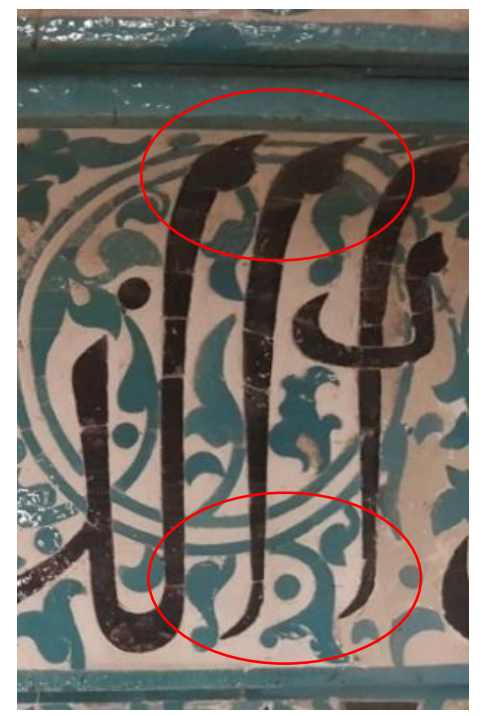

Resim 14. Mihrap yazı örneği (N. Kăgnıcı)

"Yuhidune" kelimesinin yazımı olgunlaşmış günümüz sülüs yazısına çok benzemektedir. Özellikle "nun" harfi gayet olgun bir sülüs karakteri sunmaktadır. Aynı zamanda "tı" harfinin "elifi" ise kalından başlayıp ince biterek Selçuklu sülüsünün karakteristik özelliğini vurgulamaktadır. (Resim 15)

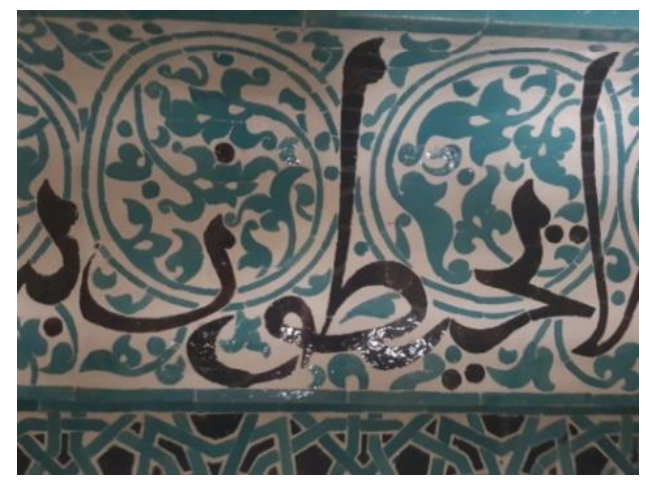

Resim 15. Mihrap yazı örnĕgi (N.Kă̆nıcı)

"Vesia" kelimesinin yazımında "vav" harfi ayın harfinin içine istiflenmiş ve uygun bir denge unsuru oluşturmuştur. "Kürsiyyü" kelimesinde ise "kef" harfi sereni güzel bir rumi deseniyle oluşturulmuştur. Aynı zamanda yazı arka planda bulunun rumi motifleriyle güzel bir arabesk oluşturmaktadır. (Resim 16) 


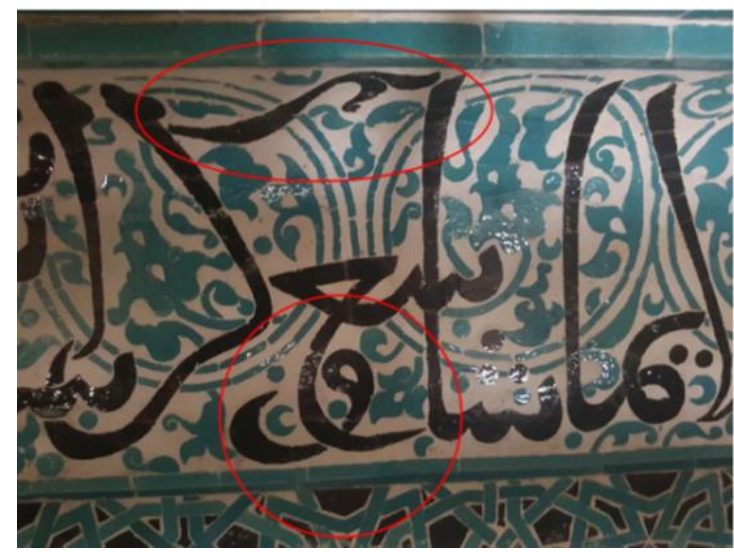

Resim 16. Mihrap yazı örneği (N. Kă̆nıcı)

"Vel arz" kelimesinin yazımında "lamelif” kullanımı dikkat çekmektedir. Diğer yazılışlarından farklı olarak alt kısmı yuvarlak yazılmıştır. Diğer yazımlarda "lamelif" harfinin "lamı" sağda "elifi" solda yazılırken bu kısımda ise "elif" sağda "lam" harfi solda yazılmıştır. Ayrıca "ra" harfinin yazılışı döneme uygun olarak mürsel şekilde yazılmıştır (Erikoğlu, 2009: 145). (Resim 17)

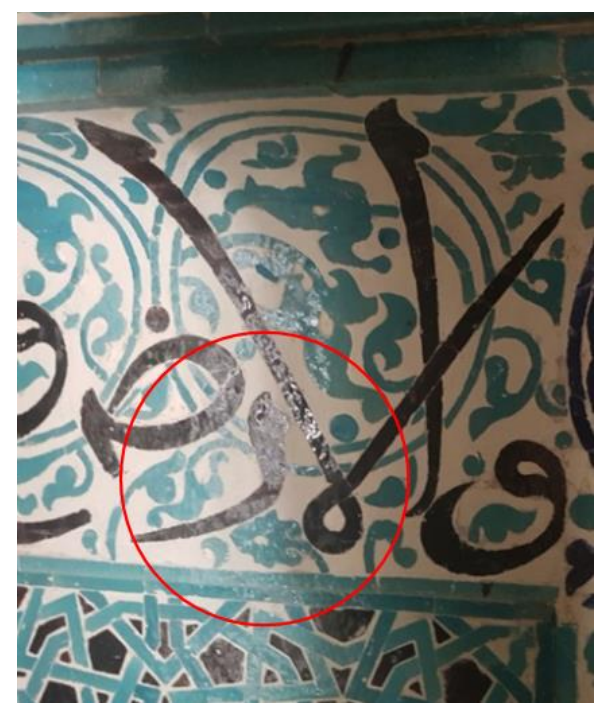

Resim 17. Mihrap yazı örnĕgi (N. Kăgnıcı)

Mihrabın sol tarafında bulunan alçı kısım yazıları "vehüvelaliyyü" kelimesi ile başlamaktadır. Orijinal kısma benzer karakterde yazılan bu kısımlarda dikkat çeken en önemli fark yazı ile desenin uyum sorunudur. Orijinal kısımda bulunan yazılar arka planda helezonik motiflerde bulunan rumi desenlerinin formları yazı tarafından bozulmayacak şekilde yerleştirilmiş ve bir bütünlük sağlanmıştır. Fakat alçı kısımda bu düzene riayet edilmeyerek harfler desenleri kapatacak şekilde gelişi güzel yazılmıştır. (Resim 18) 


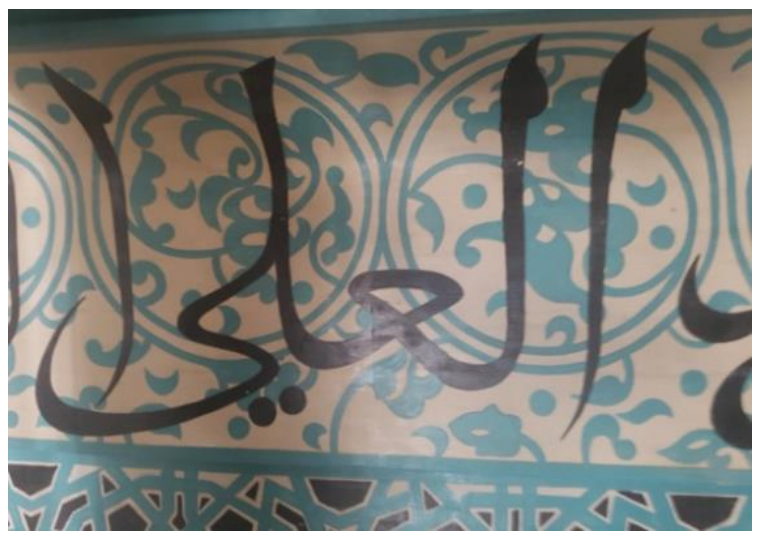

Resim 18. Mihrap yazı örneği (N.Kă̆nıcı)

"Sadekallahulazim" kelimesinin yazımında "zı" harfinin noktası unutulmuştur. Ayrıca yazının genelinde ve orijinal çini bölümde hiç kullanılmamış hareke buradaki boşluğu doldurmak için kullanıldı̆̆ı görünmektedir. (Resim 19)

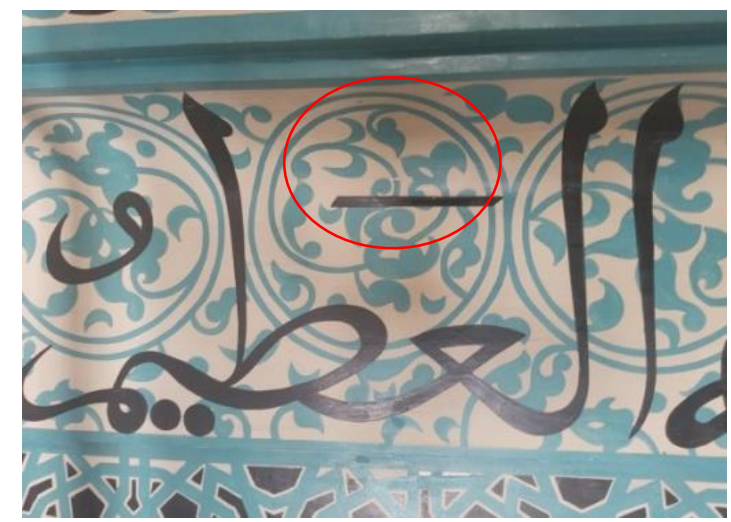

Resim 19. Mihrap yazı örneği (N. Kă̆nıcı)

Kuşak yazımızın son kısmı olan "ve bellağarasülühünnebiyyülkerim" cümlesi ile kuşak yazımız tamam olmuştur. Bu kısım yine Selçuklu sülüsünsün özelliklerini göstererek yazılmış bir cümle olarak karşımıza çıkmaktadır. "Ennebiyyü" kelimesinin üstünde bir geçmeli işaret kullanılmış ve aradaki boşluk doldurulmuştur. "El kerim" cümlesinde ise "kef" sereni bir rumi motifle tamamlanmıştır. Burada dikkatimizi çeken bir başka husus istifin durumudur. Harflerin kalan boşlukları tamamlamak adına seyrek olarak yazıldığı açıkça görünmektedir. (Resim 20)

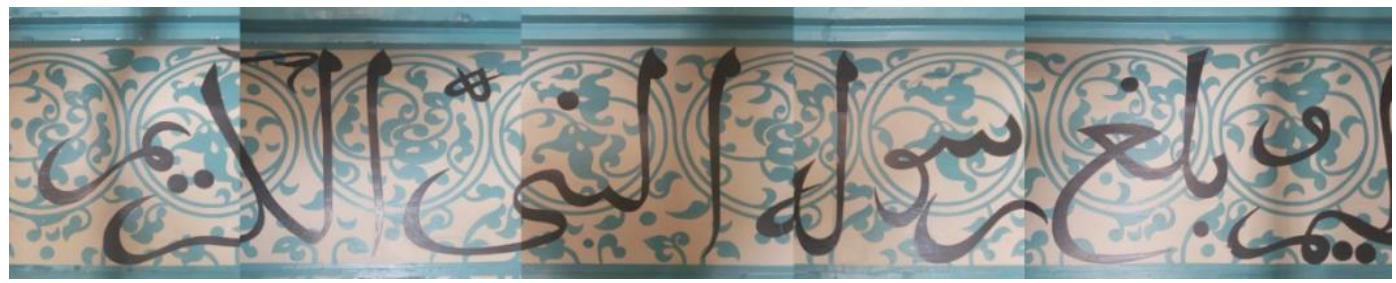

Resim 20. Mihrap yazı örneği (N. Kă̆nıcl)

\section{Mihrabın Eksik Bölümünde Bulunan Yazıların Yeniden Yazılması}

$\mathrm{Bu}$ değerlendirmeler çerçevesinde mihrabın alçı üzerine yağlı boya ile yazılmış kısımları tarafımızdan değerlendirilmiş, eksik görülen harf, hareke ve noktalama işaretleri düzeltilmiş ve ayrıca fazla görülen işaretler ve harekeler çıkarılarak kamış kalem ve is mürekkebi yardımıyla hüsn-i hat sanatının incelikleri gösterilerek yeniden yazılmıştır. (Çizim 4-5) 


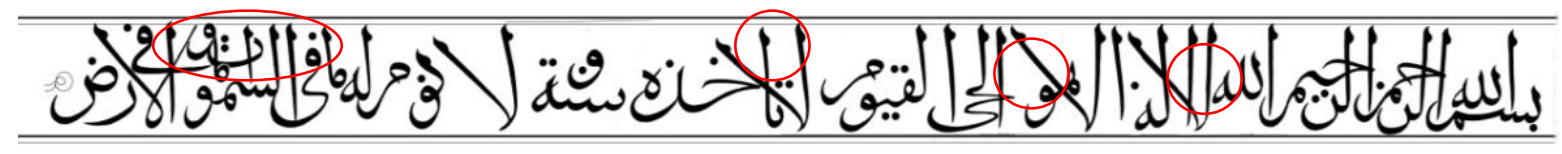

Çizim 4. Mihrabın să̆ kısmı (N. Kă̆nıcı)

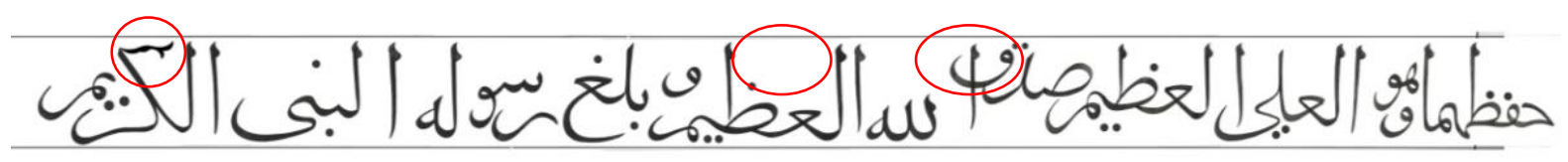

Çizim 5. Mihrabın sol kısmı (N. Kağnıcı)

Kuşak yazımızın yeniden yazılan her iki bölümünün yazıları karşılaştırmalı olarak yukarıda verilmiştir. Sol taraftaki yazıların orta kısmından itibaren seyrek olarak yazılması burada ayetin devamı veya başka bir ibarenin olduğu görüşümüzü güçlendirmektedir.

\section{DEĞERLENDIRME VE SONUÇ}

Anadolu Selçuklu devletine uzun yıllar başkentlik yapmış olan Konya aynı zamanda bir sanat ve medeniyet başkentidir. Bu dönemde yapılmış olan devletin idare edildiği Alâeddin tepesinde bulunan iç kale içerisindeki Alâeddin Camii bu sanatın ve medeniyetin günümüze 1şık tutan en büyük göstergesidir. Birçok tamir ve tadilat geçirerek günümüze ulaşan cami çeşitli eklemelerle parçalı yapılardan meydana gelmiştir. Selçuklu sultanlarının sandukalarının da bulunduğu yapı döneminin özelliklerini taşıyan mihrabı ve minberiyle ünlüdür.

I. Alâeddin Keykubat döneminde yapıldığı bilinen çini mihrap zamanla tahrip olmuştur. Çini mihrabın önüne 1889 yılında yapılan onarım sırasında mermer bir mihrap yerleştirilmiştir. Çini mihrabın dökülen diğer çini bölümleri ise alçı ile aslına uygun olarak yapılmıştır. Alçı üzerine geometrik, bitkisel desenler ve yazı ise yağlı boya ile yeniden yapılmaya çalışılmıştır.

$\mathrm{Bu}$ Makalenin ana konusunu oluşturan mihrabı çevreleyen ana bordür üzerinde ki yazı ise zemininde iç içe çifte daireler meydana getiren helezonlar ve bu kıvrımlar üzerinde bitkisel desenlerle süslenmiş Selçuklu sülüsü yazıdır. Yazıda Ayet'el-kürsi olarak bilinen Bakara suresi 255. Ayeti yazmaktadır.

Hüsn-i hat sanatı günümüze kadar çeşitli evrelerden geçerek en olgun şeklini almıştır. Her döneme ait farklı karakterleri olan bu sanatın Selçuklu döneminde kullanılan şekli ise muhakkak ve nesih yazılarının karışımı olan ve günümüze göre olgunlaşmamış bir sülüs özelliği taşıyan Selçuklu sülüsü adıyla adlandırılan yazı çeşididir.

Mihrapta kullanılan Selçuklu sülüsünün en belirgin özelliği:

- Dik harflerin kalından başlayarak ince bitmesi,

- Uçlarının sola kıvrık olması,

- Dik harflerin başlangıcında kullanılan zülfelerinrumi motifine yakın bir şekilde yapılması,

- Dik harflerin yazı içerisinde bir araya gelecek şekilde yazılmaları olarak sıralanabilir.

Mihrapta kullanılan yazı karakteri bu şartları sağlamaktadır.

Mihrabın orijinal çini bölümünde bulunan yazı dönemin karakterini tam olarak yansıtmaktadır. Harflerin birbiriyle dengeli uyumu, ahengi ve dönemine göre olgun bir özellik sergilediği açıkça görülmektedir. 
Alçı olarak yeniden yapılan alt bölümlerdeki yazılar orijinal bölümdeki yazı karakterini yansıtmakla beraber bazı yerlerinde bulunan yanlış yazımlar fazladan eklenildiği düşünülen hareket ve işaretler görülmektedir.

$\mathrm{Bu}$ değerlendirmeler neticesinde sonuç olarak alçı bölümde bulunan yazılar yeniden yazılmaya çalışılmış eksik olan kısımlar tamamlanmış, fazla olduğu düşünülen hareke ve işaretler çıkarılarak aynı ahengi yansıtacak şekilde bir düzenleme yapılmıştır.

\section{KAYNAKÇA}

Akok., M. (1972). Anadolu Selçuklu mimarisinde, geleceğin Türk sanatına kaynak olan varlıklar, Malazgirt Armağan.

Aslanapa., O. (1991). Anadolu'da ilk Türk mimarisi başlangıcı ve gelişmesi. Atatürk Kültür Dil ve Tarih Yüksek Kurumu.

Derman., U. (1987). "Hat”, Türkiye Diyanet Vakfi Íslam Ansiklopedisi, (16).

Erdemir., Y. (2009). Karatay Medresesi çini eserleri müzesi, Konya.

Erikoğlu., B. (2009). Konya'da Selçuklu dönemi yapı kitabelerinin (inşa-tamir) hat san'atı bakımından değerlendirilmesi. (Yayımlanmamış Yüksek Lisans Tezi) Selçuk Üniversitesi Sosyal Bilimler Enstitüsü.

Erzincan., T. (1989). "Mihrap”, Türkiye Diyanet Vakfi İslam Ansiklopedisi. (30).

Eyice., S. (1989). “Alâeddin Camii”, Türkiye Diyanet Vakfi İslam Ansiklopedisi, (2).

Gün., R. (1999). Anadolu Selçuklu mimarisinde yazı kullanımı. (Yayımlanmamış Doktora Tezi) Ondokuz Mayıs Üniversitesi Sosyal Bilimler Enstitüsü.

Günüç., F. (1996). “Anadolu Selçuklu mimarisinde celî sülüs hattı”, V. Milli Selçuklu Kültür ve Medeniyeti Semineri Bildirileri (25-26 Nisan 1995), Konya.

Konyalı., İ, H. (1965). Abideleri ve kitabeleriyle konya tarihi, Yeni Kitap Basımevi.

Öney., G. (1992). Anadolu Selçuklu mimari süslemesi ve el sanatları, İş Bankası Yayınları.

Önge., Y. (1966). Türk çinicilik sanatından enteresan örneklerinden İbrahim Bey imareti mihrabl, Arkitekt.

\section{GÖRSEL KAYNAKÇASI}

Plan-1: Alâeddin Camii Planı (O. Aslanapa)

Resim-1: Alâeddin Camii Mihrabı (Mustafa Cambaz), Url-1

Http://www.Mustafacambaz.Com/Details.Php?İmage_İd=19753

Resim-2: Birinci Bordür Detayı (Nihat Kağnıc1, 2019)

Resim-3: İkinci Bordür Detayı (Nihat Kağnıc1, 2019)

Resim-4: Üçüncü Bordür Detayı (Nihat Kağnıcı, 2019)

Resim-5: Dördüncü ve Altıncı Bordür Detayı (Nihat Kağnıc1, 2019)

Resim-6: Beşinci Bordür Detayı (Nihat Kağnıc1, 2019)

Resim-7: Alınlık Detayı (Nihat Kağnıc1, 2019) 
Resim-8: Mihrabın Orijinal Çini Kısmından Bir Örnek (Nihat Kağnıcı, 2019)

Resim- 9: Karatay Medresesi'nde Bulunan Yazı Örneği (Nihat Kağnıcı, 2019)

Resim-10: -20 Mihrap Yazı Örneği (Nihat Kağnıcı, 2019)

Çizim-1: Mihrap Bordürleri (Nihat Kağnıc1, 2019)

Çizim-2: Mihrap Bölümleri (Argun Kocadağıstan, 2019)

Çizim-3: Mihrabın Orijinal ve Alçı Bölümleri (Argun Kocadağıstan, 2019)

Çizim-4: Mihrabın Sağ Kısmı (Nihat Kağnıc1, 2019)

Çizim-5: Mihrabın Sağ Kısmı (Nihat Kağnıcı, 2019) 